\title{
Chinese Philosophical Viewpoints on the Natural and Humanistic Conditions of Artistic Achievement in the Italian Renaissance and Its Contemporary Implication
}

\author{
Verena Xiwen Zhang \\ Department of Philosophy, Tunghai University, Taiwan \\ Email: verena.zhang@gmail.com
}

How to cite this paper: Zhang, V. X. (2020). Chinese Philosophical Viewpoints on the Natural and Humanistic Conditions of Artistic Achievement in the Italian Renaissance and Its Contemporary Implication. Open Journal of Philosophy, 10, 9-23. https://doi.org/10.4236/ojpp.2020.101002

Received: January 3, 2019

Accepted: December 13, 2019

Published: December 16, 2019

Copyright ( 2020 by author(s) and Scientific Research Publishing Inc. This work is licensed under the Creative Commons Attribution International License (CC BY 4.0).

http://creativecommons.org/licenses/by/4.0/

(c) (i) Open Access

\begin{abstract}
This paper aims at reflecting on our life in contemporary predicament of living in "iron cage" and with "value-fragmentation" proposed from Max Weber through exploiting Chinese philosophical thoughts to synthesize the contribution from different disciplinaries. It intends to explore the issue in the Italian Renaissance but not only limited in that golden age-how could the artistic, cultural achievement in an age be possible? To explore this, issues could easily fall into describing social phenomena by using social scientific terms. When using descriptive language to depict social phenomena, we may find out lots of reasons from a higgledy-piggledy collection of phenomena fragments and social scientists try their best to give reasonable explanations for those phenomena. They have given lots of significant contributions through their research approach. However, in this paper, it aims to discover this issue through interdisciplinary approach to combine the geopolitics, macro-history, and cultural history as well as finally synthesize those perspectives and give more comprehensive picture mapped up by means of Chinese pre-Qin Daoist philosophy and pre-Qin Confucianism. In terms of geopolitics and macro history, this paper firstly attempts to explore how natural environment conditioned and affected economic development and political stability in Renaissance Venice and Florentine. In addition, it discusses whether patronage in Renaissance and Chinese Song Dynasty was merely to show off wealth or not? Furthermore, it introduces pre-Qin Confucianism to enlarge the philosophical aspect on those two questions. In Conclusion, it concludes on how pre-Qin Confucianism maps together with pre-Qin Daoism and how we can benefit from the synthetic perspectives of macro history, geopolitics, social science, and that of traditional Chinese philosophy to be in face of nowadays dilemma.
\end{abstract}




\section{Keywords}

Italian Renaissance, Geopolitics, Macro-History, Venice, Florence, Pre-Qin Daoist Philosophy, Laozi, Pre-Qin Confucianism

\section{Introduction}

This paper aims at reflecting on our life in contemporary predicament of living in "iron cage" and with "value-fragmentation" (Kim, 2017) through exploiting Chinese philosophical thoughts to synthesize the contribution from different disciplinaries. It intends to explore issues in the Italian Renaissance but not only limited in that golden age-how could the artistic, cultural achievement be possible?

To raise the question "Was the artistic achievement of the Italian Renaissance only created by a few genii, or also the representation of the social structure and the collective mind?" in that way, ostensibly, it seems to raise the question in the social scientific sense by using terms in social science. Following that social scientific approach, the answer could be described as kind of social phenomenon like an ambivalent oscillation between the pros and cons or it can also be inclusive of the whole spectrum of possibility according to descriptive language. However, the research approach to answer this question could be multiple and philosophical. For those reasons, this paper intends to exploit interdisciplinary approach combining geopolitics, macro history, cultural history, and Chinese philosophy to fulfill the research aim at reflecting on our life in contemporary dilemma, living in "iron cage" and facing to "value-fragmentation" as highlighted by Max Weber (Kim, 2017) and reemphasized by Jürgen Habermas.

In terms of geopolitics and macro history, firstly, this paper intends to explore how natural environment conditioned and affected economic development and political stability in Renaissance Venice and Florentine. Secondly, it discusses whether patronage in Renaissance and Chinese Sony Dynasty was merely to show off wealth or not? In addition, it introduces pre-Qin Confucianism to enlarge the philosophical aspect on those two questions and to avoid the risks involved anachronism. In conclusion, it concludes on how pre-Qin Confucianism map together with pre-Qin Daoist philosophy and how we can benefit from the synthetic perspectives of macro history, geopolitics, social science, and that of traditional Chinese philosophy to be in face of nowadays dilemma.

\section{Natural Environment Conditions Economic and Political Development in Venice and Florence}

\subsection{Natural Environment Conditions Economic and Political Development in Venice}

Venice, located in a lagoon at the end of the Adriatic Sea where is a pivot point 
between the western Europe and the Eastern Empire, not connected to the western Europe has her own geographical advantage and disadvantage of economic, political, cultural, and social development. Situated in a lagoon, Venice without fertile land and unsalted water is not able to cultivate grains or plants for daily needs. The lack of unsalted water is not only harmful to agriculture but also disadvantageous of developing the wool industry. Those disadvantages forced Venetians to run earn their life by making salt and ship, and trading food with the southern peninsula, Sicily, Asia Minor, and far Black Sea region. Furthermore, for separated from the western Europe, Venice is capable of avoiding the conflict between landlords and farmers, between the papacy and the Holy Roman Empire. Venetians gained the competitive advantage from natural conditions because, from geopolitical aspects, they needed not to pay taxes to the landlords and they dared to neglect the prohibition on usury because it "remained a serious inhibiting factor to the development of commerce" (Huang, 1999), even though Venice was excommunicated by the pope more than one time. Interest rate on loans charged between $20 \%$ and $50 \%$ helped Venice quickly accumulate capital and even unscrupulously (Huang, 1986, 2005). The wealth of Chinese Song dynasty at that time was equal to that of Venice but the population in Song dynasty was five hundred to thousand times than Venetian population which had been keeping in one hundred thousand (Huang, 1986, 2005).

In spite that the separation from continent benefits Venice not to be affected by the papacy and the Holy Rome Empire and helps its democratic development, the decisive factor lies in economic development which depends on international business and is contributed by shipbuilding. For Venetian business ship was also fleets and their commercial law was also civil law, Venetian businessmen had been trading in peacetime, they could quickly shift to navy in wartime. Even while fighting with rivalry, Venetian navy never forgot to exchange food and materials with their enemy and make money from their competitors. Their profit almost made Venetian fleets self-sufficient which means that naval fleets needed not to consume financial expenditure. Comparing to Byzantine flees, which was bureaucratically managed, Byzantine fleets "constituted a heavy charge on the central government's financial resources, so that whenever pressing need relaxed, the authorities in Constantinople were liable to disband the fleet as an economy measure" (McNeill, 2009). Therefore, we may conclude that Venetian economic development preconditions its politics. Now we have a more comprehensive picture as follows:

The green ellipse represents "natural world" (natural environment) inside which there is a yellow ellipse symbolizing "humanistic world" (humanistic environment) which contains economic system, political system, cultural system ... etc. If you like, you may add more and more subsystems like Pasonian models which construct systems and subsystems like Chinese cabinets of curiosities (Figure 1).

But the preference of this paper aims to pick up one relation between economic subsystem and politic subsystem to show that even using historic perspectives 


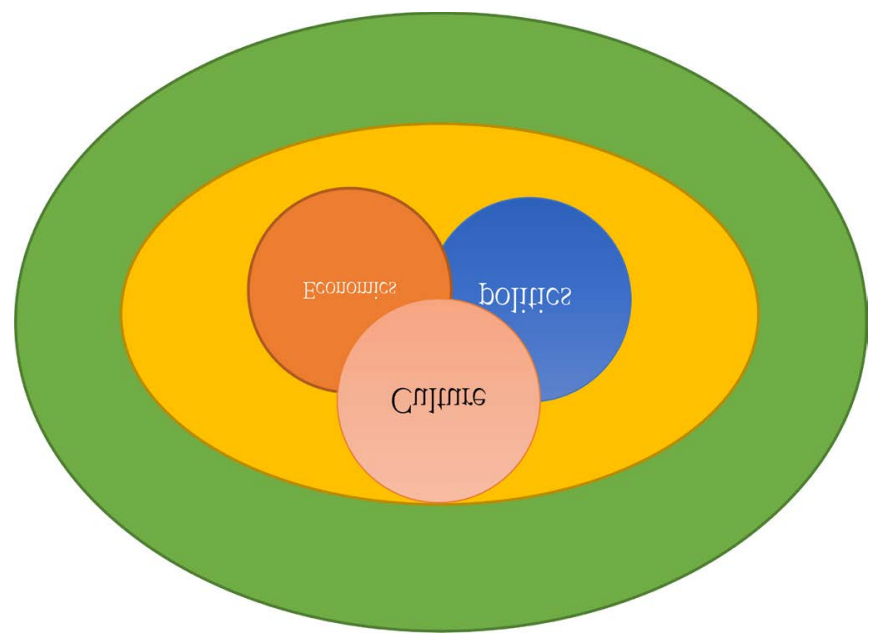

Figure 1. Subsystems in the Humanistic World.

there is no necessary to stumble into the slough of anachronism. Historians like Ray Huang with the macrohistorical perspectives (Duara, 2000) are closer to derive his compressive picture inductively from historical data like social scientist Talcott Parsons not only form his theory by deduction but also use great amount of social data to examine his theory and dynamically modify his theoretical models. Both of them are prone to discover the ultimate elements that could be universally suitable for any age to explain historical events and social phenomena. In this sense, in spite that their approach and data provided involve changeable phenomena, that doesn't mean their contribution or the problem they cared about is limited to specific times. Instead, they have great interests in ultimate problems in life. That means even we're exploring conditions and relations between Venetian economic and politic subsystems, we're not only doing so. We're searching for some ultimate elements and conditions which also appropriate for different times if they're carefully applied to ${ }^{1}$.

\subsection{Natural Environment Conditions Economic and Political Development in Florentine}

Although comparing to Pisa, Genova and Venice, Ray Huang views the natural environment limiting Florentine's marine trade opportunities as disadvantage of economic growth. As a landlocked city linking to the mass of western Europe, it unavoidably swung between the papacy and the Holy Roman Empire, and it couldn't prevent from the conflict between landlords and farmers, the upper class and lower class, both of which should be unified together by means of that both sides could be counted and managed in number before the city could be considered capitalized. On the other hand, Florentine businessmen were clever at reversing the disadvantage from national conditions by which they establish diplomatic relations to the Pope and Naples. Florentine as an active subject turned the natural disadvantage to advantage by which its businessmen in names ${ }^{1}$ I'm cordially appreciative of the comment from the anonymous reviewer. For his/her precious advice and inquiries, I have a good chance to modify this paper in a sounder way. 
of serving the Pope as tax collectors gained the privilege from the Pope so that they retain monopoly on banking and international trade. We may conclude that Florentine as an interlocked city has her own disadvantage and advantage from natural conditions. It depends on how Florentine as an active subject gains the advantage to benefit economic development.

Moreover, Tuscan Mountains and the Arno River had a great impact on Florentine economics and politics. That city situated on the imposing position next to the Arno, overlooked the other Tuscan villages like Siena, Perugia, Cortona organizing traffic networks, through the Apennines to Bologna connecting to Venice, downward the Arno river to Pisa where Florentine imported wool from Spain and North Africa (Schevill, 1963). Most important of all, the Arno river provided Florentine with sufficient unsalted water to support procedure for washing and dyeing wool. Over $2 / 3$ of its population devoted to the wool industry which wove economic system and the city as a whole (Cohn, 1980; Lindholm, 2017). It just corresponds to Fernand Braudel's saying, forming capitalism depends on it and nations are bound together. That is to say, Florentine natural environment conditions its economic development by which that city became one of the birthplaces of Capitalism and the origin of early Renaissance.

\subsection{Concluding Remark}

Section I exploits Ray Huang's viewpoint, deeply delineating the rise of Venice and Florence affected by natural geographical environment, limiting and shaping economic development. Venetian and the Florentines in face of disadvantage of situations caused by natural environment that cannot be chosen presented their wisdom as autonomous subjects, reversing the dilemma to survive among the Holy Rome Empire in the North, the Byzantine Empire in the eastern Europe, and the Islam Empire in the South. It implies that developing economic growth and political, cultural achievement conditions by natural environment. In other words, considering of "conforming to nature" and keeping ecological balance as premises is helpful to economic development. Section II follows the context of Section I and intends to explore the economic impact on artistic patronage and artworks.

\section{Was the Patronage of the Italian Renaissance Merely a Behavior of Flaunting Wealth?}

The growth of wealth and relatively political stability as a prerequisite for the development of culture and art should be no doubt, but the problem is that Venice in the country's richest state, did not take the opportunity to reach cultural and art achievement, Venetian art flourished only after the artists fled out of Italian Peninsula to avoid the war economic stability. Its cultural and artistic life was inspired by the exterior factors so that we can see, by observing the phenomenon, a wealthy country not necessarily transits from praising wealth into appreciating and creating art achievement. 
Simultaneously, the Chinese Emperor Huizong, ruled the relatively advanced wealthy and stable country in the world since $1100 \mathrm{CE}$. As an artistically gifted emperor, he sponsored many kilns, among which the Jug kiln was famous for its porcelains with remarkable quality featured by a jade-like glossy appearance. Standing out among the numerous celadon; the glaze color of Ju porcelains is famous for its slightly greenish blue like the blue sky mingled with pale gray after cleaned by a shower of rain. The imperial family designated them as royal porcelain ware (National Palace Museum, 2017). The patronage from Emperor Huizong and his royal family shows not only their wealth and political power but their decisive influence on the simplest artistic style they chose to represent their art tastes and aesthetic judgments which couldn't be estimated in a rough remark that their patronage was nothing more than flaunting wealth.

Similarly, during the middle of fifteenth century to the end of the fifteenth century, a large number of talented artists Leonardo da Vinci, Michelangelo, Raphael, Giorgione, Titian, Paolo Veronese, Correggio and others, accompanying many outstanding artists, hundreds of unknown art creators. In addition, famous sculptors like Lorenzo Ghiberti, Donatello, architects like Filippo Brunelleschi, Michelozzo Michelozzi and numerous patrons, amateurs, common people and proletariat were capable of appreciating masterpieces and art works. In terms of the cultural system in the Italian region, the research conducted by Peter Burke investigates the distribution of 600 creative elites, more than $1 / 4$ artists of whom came from Tuscany. Over $1 / 3$ of 600 creative elites coming from Tuscany and the Pope State implies the discourse in Section 3which proposes relatively wealthy countries support art achievement (Burke, 2014). "The creative elite appears to have been biased socially as well as geographically" (Burke, 2014). Their father's occupation in $47 \%$ of the group cannot be traced; the other $43 \%$ almost came from a limited social background. Among the remaining $43 \%$ of them, 114 were later generation of artisans and shopkeepers, 84 were noble and 48 were the next generation of merchants and professional men. Only 7 of them came from the classes of peasants and agricultural labourers (Burke, 2014). "In fact, the artists tended to be the children of artisans and shopkeepers..." (Burke, 2014). The research shows that artist dynasties have great influence on cultivating creative artists. The Victorian scientist Francis Galto appealed to explicate the phenomenon from "hereditary genius" is the approach of appealing to biological explanation which taken as an external explanation on the philosophical viewpoint, so does Section I and Section II of this paper appeal to geopolitical explication. The sociological explanation of why the artists flourished in Renaissance Italy also appeals to external explanation in respect to pursuing the philosophical source of phenomenon. Here we end with Burke's conclusion: "The most favourable environment for artists to grow up in seems to have been a city which was oriented towards craft-industrial production, like Florence, rather than towards trade or services, like Naples or Rome. It was only when Venice turned from trade to industry, at the end of the fifteenth century, that Venetian art caught up with that of Florence" (Burke, 2014). 
The usage "external explanation" means appeal to the factors outside the phenomenon such as natural environment or social environment, instead of exploring its inner root in terms of philosophical framework.

\section{Concluding Remark}

Although the natural and the social environments are external conditions to explain the Renaissance artistic achievements, they are still not the essential elements sufficient to promote artistic activities and advance the achievements of artistic creations. All we need is to find out some kinds of "supervenient" elements instead of merely exploring the external elements. Handicraft industry is particularly different from business and trade, the end product through hands and human spirit/awareness/consciousness shows the inner, spiritual states of artists, their personal characters as well as special artistic styles. Thus, the "distinctive characters" of the Renaissance art patronage, which cannot be simply attributed to showing off people's wealth, lie in more essential elements associated with inner spiritual realms of human consciousness as well as inborn talents. Furthermore, art achievements of are not merely relied on artists' inborn talents and perfect skills. During the Renaissance, art patrons communicated with intermediaries and artists through correspondence and contracts, implementing the artistic styles specified by sponsors, as well as regulating which kind of raw materials must be used, and which biblical stories or the ancient Greek and Roman deeds must be incorporated. All of them represent the patron's aesthetic tastes and their criterion of aesthetic judgment.

Although appealing to natural conditions and social environment are external explanations to artistic phenomenon, they just fit our ideas that wealth and stability of a country are necessary to promote art creation, but they're still not enough! In the cases of Renaissance Venice and Florentine, the character of trade or services was different from that of craft industry by which humans connect to others and even themselves through their own hands. The handicrafts represent the producers' spiritual states, personal characters and artistic styles which have supervenience on trade or services. R. M. Hare is the first one to use the term "supervenience" borrowed from British Emergentist Lloyd Morgan (Melaughlin \& Bennett, 2018) but not the alike Morgan's usage. Before R. M. Hare, G. E. Moore proposed the idea but not use the term, he asserts that "one of the most important facts about qualitative difference... [is that] two things cannot differ in quality without different in intrinsic nature" (Moore, 1922). After Moore and Hare, Donald Davison applied the idea into philosophical itself:

"Mental characteristics are in some sense dependent, or supervenient, on physical characteristics. Such supervenience might be taken to mean that there cannot be two events alike in all physical respects but differing in some mental respect, or that an object cannot alter in some mental respect without altering in some physical respect" (Davidson, 2002).

In terms of supervenience, patronage in Italian Renaissance or in Song Dy- 
nasty cannot be simply reduced to behaviors of flaunting wealth, for those art activities and art works were not with physical characteristics but more important, they contain mental features relating to mind and spirituality. Patrons communicated with artists through correspondence and intermediaries, conducting the orientation toward which kind of artistic styles, what kinds of rough materials, minerals, colors, how many characters or things should be included in the artworks they ordered. All of those activities present patrons' artistic tastes and aesthetic standards.

\section{How Does Chinese Pre-Qin Philosophy View the Above Two Questions?}

To explain whether the phenomena of artistic patronage in Italian Renaissance was just to flaunt wealth or not, this section tries to explain it in respect with Chinese philosophy, exploring the internal root of human nature, different from the external interpretation of geopolitical, historical, sociological perspectives based on the experimental materials. During the Italian Renaissance, a lot of humanist scholars and philosophers made efforts to explain human nature, but their explanation on the level of phenomenon, by which the discussion on human nature always mixed goodness with evil, because in phenomenon, human behavior often mixes goodness with evil. Machiavelli's The Prince intended to advice monarch from the perspective of that human nature basically is evil. While some other humanist scholars argue that human nature is good or human nature just mix good with evil, or it does not matter whether human nature is good and evil, and finally they all need for God's salvation. In Part 3, we already mention that the high achievement art masterpieces can never be separated from the artists and how their contemporaries feel, what they think and why they approve or disapprove a thing. Renaissance humanists and philosophers have profound influence on their artists' thoughts. For the above reasons, Section III of this paper firstly introduces pre-Qin Confucianism on human nature as a response to the western discussion on that. Moreover, thinking about human nature is to explore the essence of all human beings which is not limited to the specific geographical environment nor restricted by particular humanistic traditions; therefore, applying Confucianism on human nature to the question of whether Renaissance art achievement is only a talented artist's performance, or also contains the social structure and the collective social mind of the presentation has its applicability.

Here I borrow Huiling Lai's categories on human nature: 1) human nature is rooted in goodness, proposed by Mencius; 2) human nature is evil, which has two branches: human nature is rooted in evil, human nature is inclined to be evil; Xunzi was on behalf of the latter; 3 ) human nature is mixed with goodness and evil; most previous scholars supported that; Yang Xung, Ouyang Xiu, Wang Chung, Huang Fushi, Han Yu and SimaGuang were the representative (Lai, 1995); 4) human nature has no relation to goodness and evil; Gaozi supported 
this viewpoint. According to Lai's lecture ${ }^{2}$, no matter which category one support, one should answer to questions from the opposite. Those who choose category (1) should answer to the question: if goodness is the source of human nature, where comes evil? Anyone who supports category (2-1) should respond to the doubt: if evil is the source of human nature, where comes goodness? Doubts of (2-2): if human nature is inclined to be evil, why is the whole part of human nature inclined to evil? Those who support category (3) basically explain nothing but describe the experimental phenomenon. They also need to face some questioning: a) How is it possible that human nature is mixed with goodness and evil? b) How to explain the proportion of goodness and evil and by which way they're mixed together? One who chooses category (4) since human nature has no relation to goodness and evil, it finally has the inclination to be evil. Therefore, one has to explain why human nature is inclined to evil.

Confucianism on human nature is a big, complicated system; it cannot be discussed in detail comprehensively. Because Category (1) is to be used to explain two questions mentioned in Section I and Section II, here we provided a better focus for the Mencian meaning of human nature based and rooted in goodness. Mencius defined his theory of goodness in human nature as following:

"... that by which man is distinguished from the birds and beasts is almost negligible, the common man discards it, the gentleman keeps it enact" (Graham, 1976).

In other words, although essence of human nature is goodness which is the most distinct to distinguish human beings from animals, the most part of human nature mixed up with characteristics of animals-needs, desires, and instinct. Goodness is the fewest part in human nature so that human beings need to practice and expand goodness in daily life if they as common people expect to transform into gentlemen or lady rather than morally degenerating into villains. The main point proposed by Lai is that Mencius' meaning of goodness refers to the essential meaning in theoretical sense that everybody has goodness, instead of saying that everybody's representations of human nature are purely good. The latter refers to real status in which human beings experimentally embody goodness in real daily life. From theory to practice, the difference between saint, common people, gentleman, and villain lies not in the theoretical meaning of goodness but in the posterior behavior. By this context, if one doesn't act rightly or behaves badly, it's because of "the absence of goodness" in an experimental sense rather than in theoretical sense.

If the purpose of patrons only to flaunt wealth without any aesthetic requirements, from the aspect of pre-Qin Confucianism (Ruism) on human nature, such kind of phenomena can be explained as "the absence of goodness". Because of wealth, more of them can benefit from leisure time to ponder who to live a valuable life and to expand the little part of goodness in our human nature. For ${ }^{2}$ Huiling Lai is an associate professor, Center for General Education, I-Shou University, Taiwan, Republic of China. The lecture was delivered by Lai and the author of this paper took the notes on the lecture at I-Shou University in May 29, 2017. 
we have already mentioned in the previous paragraph that although Mencius had proposed the root of human nature is goodness by which the difference between animals and humans was made. Goodness as kind of supervenience elements added on human nature in which contains other components like needs, desires, instincts. In the Italian Renaissance, patrons were from various social classes, from the nobility, wealthy gentry, and common people, from different kinds of organizations including bishops, cathedrals, churches, brotherhood and all kinds of guilds, even common people and proletariat were capable of appreciating and admiring masterpieces and art works. The aesthetic taste, judgment and the competence of purchasing art works and the activities of patronage had been prevailing among them and permeating the whole society, especially Florentine and Venice. In terms of human nature metaphysically rooted in goodness, the patronage of aristocracy and the wealthy family not necessarily completely in pursuit of flaunting their wealth; instead, it can be viewed as an external representation on which their inner goodness reflected. Those kings and queens, the bishops, the aristocracy, the rich, bankers and businessmen can not necessarily invest to promote art, even if they tried to flaunt wealth and political power, to promote their own reputation, there are still lots of means to do that. Since childhood those people generally accepted good humanistic education, philosophy of life and the activities of artistic appreciation had become an indispensable part of their daily life and many of them not only sponsored art activities, they also devoted themselves into the artistic creation. Pursuing wealth has nothing wrong for it's a basic need in our human nature. But for some people, it's not enough to spend all their life just pursuing wealth, there is some other kinds of value belonging to spiritual instead of material and that's why only pursuing wealth and power cannot replace the value of spiritual kinds, like demands for aesthetic activities, art creation, moral practice, and discovery of scientific truth, and self-fulfillment. Therefore, Mencius' philosophical thinking as a main branch of pre-Qin Confucianism aims to explore and emphasize on the source of human nature based on goodness which is prior to all kinds of experimental phenomenon. From the source of human nature, we would never be confused with phenomenon in which the wealth prefers showing off to pursuing other kinds of value without any harm from it. But we would be very aware of the deepest root of human nature-goodness/renxinrenxing-by which human beings have a higher demand for fulfilling their ideals like aesthetic value. If the rich understand the insufficiency of their talent and therefore much more treasure those genii's aesthetic contribution, the patronage in Italian Renaissance is not only an external representation from their inner goodness but they also practice moral actions in which they're not jealous artists' talent but conscious of cultivating their talent by their private fortune. Thanks to their goodness, wisdom, and generosity, we as later generations rather than their contemporaries still can appreciate those brilliant masterpieces in museum, art gallery, church and cathedral. Those who visited the splendid Medici Riccardi Palace and Uffizi Gallery would have aesthetic comprehension on those master- 
pieces and art works. At twilight, halting before Plaza Michelangelo, looking down the Brunelleschi's dorm dotted with golden-rose sunlight, time silently rolling by, evening stars peeping out of layers of colorful clouds, seeing the Arno dotted with silver-bright starlight, with the clear image of the brightest moon, one may understand what kind of wealthy collective, not only materially but also spiritually, they had been so that they as a whole were bound together to create high-level art achievement in the course of human civilization. In addition, we also pay respect to those genii's contributions because their art achievement depends not only on their talent which we're not possessed of but also on their endeavor to self-fulfillment.

\section{Conclusion}

1) The notion of Laozi's "conforming to nature" is not contrary to the Pre-Qin Confucianism on "human nature", but complements to each other.

Human being as an acting subject can be consciously autonomous. Mencius has proposed the principle of "the essence of being human". This principle is natural in terms of conforming to the principle; human can extend three levels of human nature: the level of claim to truth, the level of claim to goodness, and the level of claim to beauty. Pre-Qin Confucianism on human nature is suitable for the application to individuals, various social groups like artists and patrons, and notions. Thanks to the wise choice of the supervisor of the work of the Cathedral of Santa Maria del Fiore, The copy of The Giant, David made by Michelangelo have situated in the SignoriaPlazza until now. There's a short episode behind this achievement. Originally, the supervisor owned a piece of large marble, brought one hundred years ago by a sculptor with mediocre technique the Carara quarry and he sketched on it. For one hundred years no one had been courageous and confident enough to carve that stone into beautiful statues. A man named Andrea dal Monte bought the marble from the supervisor and made some standards asking them to carve a statue, but the supervisor wrote to $\mathrm{Mi}$ chelangelo before making up his determination to sell the marble. Since that time, Michelangelo had just finished the Pieta, which was appointed by the cardinal San Dionigi and now preserved in Vatican. The holy, elegant artwork Pieta brought Michelangelo high reputation so that his supervisor thought it was necessary to inquire Michelangelo how to deal with that large marble. As soon as Michelangelo replied to the supervisor that he could transform this piece of marble into a beautiful artwork, the supervisor immediately decided to give the marble to Michelangelo. This is an individual case that supervisor in accordance with its human nature, with his conscience to make the decision wisely, for the criterion of judgment by which he should give the marble to whom was not dependent on much they would pay, but on how much artistic value they could create-Anyone who was capable of creating invaluable artwork should own the marble.

In addition, there have been endless phenomena that make people act between 
good and evil, moral and immoral. There had been a study shown that the researchers believe that a patron in the selection of many artists by the measurement of the price, but the record found after his study showed that the patron had seriously considered the individual art style of each artist and the criterion to choose the suitable artist and work was artistic style rather than the price. The price of chosen one was higher than those prices not chosen. Some points of these individual phenomena are worth noting: a) Moral actor with their goodness (renxinrenxing) can be conscious of making right choice; b) The meaning of "nature" in the notion of "conforming to nature" refers to "the ultimate principle of the universe", named as "Dao" which is "the principle of creating everything in the universe" (Wang, 2017), such as the Big Bang Theory and the Higgs discovered in natural science. On the other hand, there are also principles of how to be human in the Confucianism, by which human comply with to become a gentleman and even into a sage. Therefore, those principles of being human in Confucianism on humanity are natural to human, as long as the practice of goodness do not overact and conflict with natural needs of instincts inside our human nature, Daoists have no objection to Confucianism on the essence of human nature; on the contrary, not only have no objection against Confucianism, but also supports the Confucianism on the essence of human nature. Moreover, Laozi's "Dao" refers to "the principle of creating all things in the universe" (Wang, 2017), and "De" refers to "the principles of the essence of all things" (Wang, 2017), which is the principles of "everything thing has its own principle of being itself", that is to say, "All things are created by Dao, but they have their own 'essence' to be a thing and different things have different essence..." (Wang, 2017). Following this context, the Renaissance carving as a profession has its own principles in carving techniques and aesthetic judgments recognized by its members. For instance, for the past century by Renaissance, no sculptor dared to carve on the marble which finally carved by Michelangelo. The reason is that they didn't think they could conform to natural shape and its texture to create the beautiful sculpture. But Michelangelo had this self-confidence, when the work was completed, David s head and the base preserve the rough surface of the original stone. Michelangelo often said that in the process of carving stone, to correct the natural flaws is extremely difficult. In other words, consciously or unconsciously, the great sculptors conform to the principle of artistic creation within their professional field-only when they follow the principles recognized in their field, they can create beautiful and great works. Therefore, the Daoist notion of "conforming to nature" does not conflict with the Confucianism on the essence of human nature, which emphasizes the pursuit of three kinds of values-truth, goodness, and beauty.

Florentine as an interlocked city-state connected to the continent of western Europe has its inherent advantages and disadvantages, it depends on how the Florentine wisely use them. The hidden worries caused by its linking to western European continent had made Florentine impossible to get rid of the political 
conflict between the papacy and the Holy Roman Empire. On the other hand, the Florentine businessmen through this natural restriction to establish an inseparable power relationship between the papacy States and the Neapolitan Anvegin dynasty, which privileged Florentine businessmen to monopolize international banks and international trade when they collected taxes for the Pope. Florentine businessman as active subject/agency with wisdom turned the disadvantage of natural geography by conforming to nature in order to benefit their conditions of surviving economically and politically, and even became one of the birthplaces of Capitalism and created the marvelous early Florentine Renaissance.

2) Natural geographical environment and climatic conditions precondition and have a great impact on economy, politics, and national security.

The Daoist notion of "conforming to nature"- "Adapting to nature" can make a country understand its inherent limitations, by which a nation firstly searches for wealth and stability to survive and then there's possibility of cultural and artistic development. Under the constraints of congenital conditions, seeing their realistic status in international relations clearly can develop the win-win strategies in accordance with self-interests and international interests. In this way, a nation would not be marginalized out of international society to damage its self-interests and succession. The Daoist notion of "conforming to nature" has its importance in modern society. Geographical environment and climate also have their own natural laws of development. Setting the declination of Venice as a warning, the glorious rise of Venice depends on its adaption to nature and the declination of Venice is also preconditioned by violation of natural laws. After the mid- $16^{\text {th }}$ century, due to the natural regeneration of forests failed to catch up with the pace of destruction caused by wildfire or grazers set fire for attaining much pasture, Venice face the wood shortages which not only stroke the industry of Venetian fleets but also inflicted severe damage on its economic system. Not being conscious of conforming to natural laws had let pay higher price than it had imagined. McNeill proponents:

"Once woodland had been cut over, the rays of the Mediterranean sun were so strong that young seedlings were liable to wither and die in the dry season. In a mature forest, the shade of established trees could prevent excessive desiccation; but in many Mediterranean landscapes, once big trees had disappeared, natural regeneration could become extremely slow, or even come completely to a halt' (McNeill, 2009).

Because of the shortage of timber in Italy, the wood purchased from the far Nordic Forest was expensive. The rise of the Spanish and Portugal fleets assembled warships and merchant ships more efficiently, so the maritime hegemony of Venice quickly declined.

According to Ray Huang, the decline of maritime hegemony and economic power of Venice can still be examined from the perspective of geopolitics. Venice, with its tiny territory and with small amount of population always kept around one hundred thousand, has no natural mineral resources except for sea 
salt, has no grains for its people and has no wood for manufacturing fleets and merchant ship, once other competitors with larger population and territory facing the oceans actively explored the routes to the Americas and other regions to import the necessary minerals and other resources for Europe. If necessary, they can cut off the source of imports of raw materials, Venice would be in a very difficult situation (Huang, 2005).

Giddens in his The Politics of Climate Change points out:

"The US is already starting to see the world through the prism of a struggle for energy resources against the backdrop of damage inflicted by climate change... The global reach that China is seeking to establish, it argues, is driven by the demands of its economy for raw materials rather than by any specific ideological outlook' (Giddens, 2011).

Russia is also suffering from high prices for raw materials such as oil, natural gas and mineral resources. In terms of geopolitical perspective, Russia begin to pay attention to the impact of the natural environment on national security and economic development. In conclusion, from the perspective of Daoist philosophy we advocate that being part of nature, human beings should be conscious of seeking balance between "Humanistic World" and "Ecological Balance" in the process of developing human civilization. Only when the principle of conforming to nature is considered seriously, human beings may relatively continue processing and promoting our civilization. When we overly violate natural laws, we are unconsciously toward the decline of human civilization. Furthermore, advocating "conforming to nature" and seeking "ecological balance" from Daoist philosophical perspective does not necessarily lead to "anti-modernization". We have pointed out in the first part of our conclusion that the pre-Qin Daoist notion of "conforming to nature" does not conflict with the thought of the pre-Qin Confucianism (Ruism) on human nature". To expand the human conscience and innate goodness, to search for realizing ideal on three different levels, that is, demand for realizing truth, moral goodness, and beauty, those searching rooted in Confucian thinking framework of "humanism based on human beings", should be incorporated into Daoist thinking framework of "naturalism based on human beings" because the balance between the natural environment and the survival of mankind has already been with great urgency.

\section{Conflicts of Interest}

The authors declare no conflicts of interest regarding the publication of this paper.

\section{References}

Burke, P. (2014). Chapter 3: Artists and Writers. In P. Burke (Ed.), The Italian Renaissance: Culture and Society in Italy (3rd ed., pp. 47-93). Cambridge: Polity Press.

Cohn Jr., S. K. (1980). Chapter 3: The Popolo Minuto. In S. K. Cohn Jr. (Ed.), The Laboring Classes in Renaissance Florence (p. 71). New York: Academic Press. https://doi.org/10.1016/B978-0-12-179180-3.50011-7 
Davidson, D. (2002). Essay 11: Mental Events. In Essays on Actions and Events (2nd ed., pp. 207-224). Oxford: Clarendon Press. https://doi.org/10.1093/0199246270.003.0011 https://bibliotecamathom.files.wordpress.com/2012/10/essays-on-actions-and-events.p df

Duara, P. (2000). Broadening the Horizons of Chinese History: Discourses, Syntheses, and Comparisons. The American Historical Review, 105, 880. https://doi.org/10.2307/2651815

Giddens, A. (2011). Chapter 9: The Geopolitics of Climate Change. In The Politics of Climate Change (2nd ed., pp. 203-227). Cambridge: Polity Press.

Graham, A. C. (1976). The Background of the Mencian Theory of Human Nature. Tsing Hua Journal of Chinese Studies, 6, 238.

http://thjcs.web.nthu.edu.tw/files/14-1662-70088,r4202-1.php?Lang=zh-tw

Huang, R. (1986). The Rise of Capitalism in Venice, the Dutch Republic, and England: A Chronological Sketch. Chinese Studies in History, 20, 3-50.

https://doi.org/10.2753/CSH0009-463320013 http://www.tandfonline.com/doi/abs/10.2753/CSH0009-463320013

Huang, R. (1999). Chapter 5: Capitalism in Venice, the Dutch Republic, and England. In R. Huang (Ed.), Broadening the Horizons of Chinese History: Discourses, Syntheses, and Comparisons (An East Book Gate) (pp. 169-181). Armonk, NY: M. E. Sharpe.

Huang, R. (2005). Chapter 2: Venice. In Capitalism and the Twenty-First Century (Ziben Zhuyi yu Ershiyi Shiji) (14th Print, pp. 37-86). Taipei: Linking Books.

Kim, S. H. (2017). Max Weber. The Stanford Encyclopedia of Philosophy (Revision). https://plato.stanford.edu/archives/win2017/entries/weber

Lai, H. (1995). Critique on Chen Lee's "Dongshu Reading Notes" on the Meaning of Goodness in Human Nature. Journal of modern literature in Chinese, 8, 307-330.

Lindholm, R. T. (2017). Chapter 3: The Chances of Getting Rich in Renaissance Florence: The Wool Industry Occupational Wealth Hierarchy. In D. S. Reinert, R. Kattel, \& W. Drechsler (Eds.), Quantitative Studies of the Renaissance Florentine Economy and Society (pp. 61-96). Madison, WI: Anthem Press.

McNeill, W. H. (2009). Chapter 1: The Frankish Thrust into the Levant, 1081-1282. In W. H. McNeill (Ed.), Venice: The Hinge of Europe (1081-1979) (pp. 1-45). Chicago, IL: The University of Chicago Press.

Melaughlin, B., \& Bennett, K. (2018). Supervenience. The Stanford Encyclopedia of Philosophy (Revision). https://plato.stanford.edu/archives/win2018/entries/supervenience

Moore, G. E. (1922). The Conception of Intrinsic Value. In Philosophical Studies (p. 263). London: Routledge \& Kegan Paul.

National Palace Museum (2017). Grand View: Ju Ware from the Northern Song Dynasty. Taipei: Natioanl Palace Museum. https://www.npm.gov.tw/exh95/grandview/juware/index_en.html

Schevill, F. (1963). Etruscan and Roman Florence. In Medieval and Renaissance Florence (Vol. 1, pp. 3-11). New York: Harper \& Row.

Wang, H. (2017). Exploration on the Meanings of Laozi (2nd ed., pp. 326-327). Taipei: The Commercial Press. 